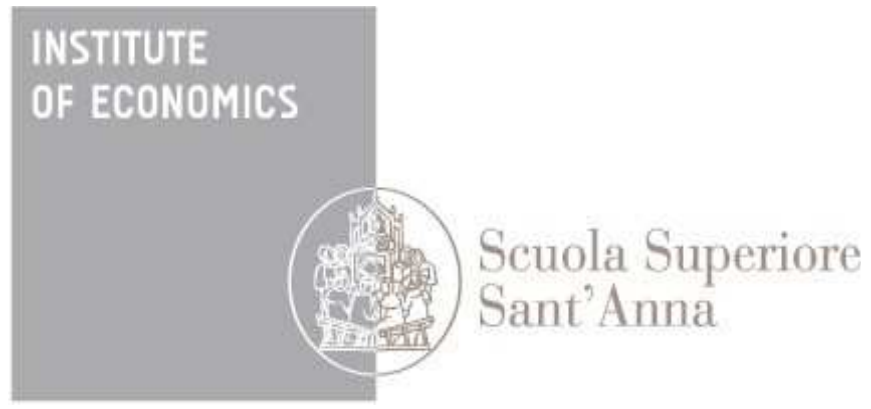

LEM | Laboratory of Economics and Management

Institute of Economics

Scuola Superiore Sant'Anna

Piazza Martiri della Libertà, 33 - 56127 Pisa, Italy ph. +3905088.33 .43$

institute.economics@sssup.it

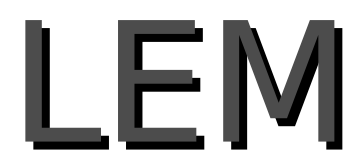

Working Paper Series

\title{
The demand-pull effect of public procurement on innovation and industrial renewal
}

Francesco Crespi *

Dario Guarascio ${ }^{\circ}$

${ }^{*}$ Roma Tre University, Rome, Italy

${ }^{\circ}$ National Institute for the Analysis of Public Policies - INAPP, Rome, Italy 


\title{
The demand-pull effect of public procurement on innovation and industrial renewal
}

\author{
Francesco Crespi ${ }^{\mathrm{a}}$ and Dario Guarascio ${ }^{\mathrm{b}, \mathrm{c}^{*}}$ \\ ${ }^{a}$ Roma Tre University, Rome, Italy \\ ${ }^{\mathrm{b}}$ National Institute for the Analysis of Public Policies - INAPP, Rome, Italy \\ 'Sant'Anna School of Advanced Studies - Pisa, Italy
}

\begin{abstract}
This article analyzes, empirically, the link between public procurement and innovation activities by taking into account the moderating effect played by import penetration on public procurement. Using industry-level information on patent applications for 24 countries over the period 1995-2012, we test the impact of public procurement on innovation activities and whether and in which direction import penetration on public procurement impacts on patenting. The econometric analysis relies on Poisson regression techniques aiming to investigate the correlation between patent counts, supply as well as demand-side determinants, controlling for country and sector heterogeneity. The obtained results confirm our main hypotheses. The dynamics of patenting is positively affected by the public procurement while a high degree of import penetration reduces the innovation enhancing effect exerted by public demand. Our results suggest that public demand may represent an effective tool for industrial policy to stimulate innovative activities, to shape the transformation of production systems and to foster industrial renewal. Moreover, the empirical evidence shows that the strategy regarding the degree of openness in public procurement towards non-domestic firms is a crucial policy choice capable of affecting the innovative potential of public demand.
\end{abstract}

JEL codes: O25, O30, O31, O49

Keywords: Public procurement, innovation policy, demand-side innovation policy

*Corresponding author: d.guarascio@inapp.org 


\section{Introduction}

The term 'public procurement' (PP, hereafter) is used to identify the direct purchase of goods and services by the public sector. In 2015, PP accounted for a share of about $12 \%$ of the OECD countries' GDP and almost $30 \%$ of their national public spending. ${ }^{1}$

PP has been used as a policy instrument in pursuit of different goals: increasing aggregate demand, stimulating production and job creation, protecting domestic companies from global competition by encouraging investment and growth, increasing competitiveness of 'national champions' by fostering their innovative capacity and, finally, reducing regional disparities (Edquist and Hommen, 2000). No less significantly, PP is a key industrial and innovation policy tool. In fact, it can accelerate productive system upgrade, encouraging the development of sectors characterized by greater technological intensity, creating new markets and stimulating demand-driven innovative investments (Rothwell, 1983; Weiss and Thurbon, 2006; Chang, 1994; Gerosky, 1990; Wade, 1990; Edquist et al. 2000, Mazzucato, 2013).

In recent years, increasing attention has been paid to demand-side policies to foster innovation (Edler and Gheorghiou, 2007; OECD, 2011; Gheorghiou et al. 2014) and PP has been identified as a key instrument of innovation policy in both the developed and developing countries (Uyarra and Flanagan, 2010; Crespi and Quatraro, 2013; Mazzucato et al. 2015; Edquist, 2015). The key role of PP appears to be particularly important in the current economic situation. The 2008 crisis has led to a sharp decline in levels of economic activity and employment, especially in the manufacturing sectors. In Europe, the crisis has led to growing polarization in terms of employment, competitiveness and industrial specialization (Simonazzi et al., 2013, Cirillo and Guarascio, 2015; Lucchese et al., 2016; Andreoni and Chang, 2016). In this scenario, PP is seen as a useful tool to reverse the economic trend characterizing the majority of EU economies (Mazzucato et al. 2015). Public demand for goods and services could play a crucial role in macroeconomic terms, supporting aggregate demand and employment, but also reviving those innovative investments that are essential for sustaining industrial renewal, international competitiveness and economic growth in the long run (Chang and Andreoni, 2016). Moreover, orienting public demand towards specific areas and firms can help to strengthen the regions and sectors more seriously harmed by the crisis.

Directing public demand towards one or more specific production sectors represents a relevant strategy to promote the emergence or consolidation of production and markets characterized by high growth prospects (Pasinetti, 1981; Pianta, 2015; Mazzucato, 2016). This appears to be of

\footnotetext{
${ }^{1}$ Source: OECD - Government at a glance 2015 database (http://www.oecd.org/gov/government-at-a-glance-2015database.htm)
} 
particular relevance in high-tech industries, where returns on $R \& D$ investment are particularly uncertain. Thus, public procurement can produce an exogenous increase in demand for high-tech goods and services, stimulating innovation activities to capture these demand flows (Leon, 1966; Pasinetti, 1981).

After the crisis, however, not all countries followed the same strategy. The United States included public procurement among their main countercyclical tools. Public investments have been directed towards upgrading the infrastructure network as well as fostering high-tech and green sectors (Wade, 2017). Moreover, the US has sought to maximize the impact of its government spending with a strategy focused on domestic purchase of products (the so-called 'Buy American' strategy compelling the government to purchase only domestically produced goods and services). By contrast, the EU responded to the crisis adopting deflationary policies designed to consolidate member states' public budgets. For these reasons, many European countries have seen a reduction rather than increase in the scale of public procurement. Furthermore, the EU institutions in no way encouraged increase in the domestic content of public procurement (i.e. no measures like the 'Buy American' have been adopted in Europe).

The aim of this work is to analyze the relevance of the demand-pull influence of PP on innovation activities at the sectoral level. Moreover, by means of panel data econometrics we investigate whether, and if so to what extent, import penetration of public procurement exerts a moderating effect in shaping the relationship between PP and the innovative activities of industries. In so doing, we will try to shed light on a possible trade-off between static and dynamic efficiency that should be taken into account in policy choices regarding PP strategies. The analysis draws upon a rich dataset providing industry-level information on economic performance, public procurement, international trade and production as well as $\mathrm{R} \& \mathrm{D}$ expenditure and patents for all manufacturing industries - 2-digits Nace Rev. 1 - in 24 countries over the period 1995-2011. ${ }^{2}$ In particular, sector level information on PP is derived from the WIOD database, which collects Input/Output tables for a large set of countries. ${ }^{3}$

The article is organized as follows. In the next Section, we review the relevant literature and spell out the research questions that we address in the empirical analysis. Section 3 describes the database adopted and construction of variables; and traces out a descriptive picture of the dynamics of PP through time and import penetration in the EU and in the major OECD economies. Model,

\footnotetext{
${ }^{2}$ Austria, Belgium, Czech Republic, Germany, Estonia, Finland, France, Greece, Hungary, Ireland, Italy, Japan, Korea, the Netherlands, Poland, Portugal, Romania, Russia, Sweden, Slovenia, Slovak Republic, Spain, Turkey and the US.

${ }^{3}$ Input/Output data represent the best available approximation in standard statistics to obtain a sector based breakdown of government procurement (Ramboll, 2009; Appelt and Galindo-Rueda, 2016).
} 
econometric strategy and results are presented and discussed in Section 4; while Section 5 concludes providing some general remarks.

\section{Literature background}

\section{The demand pull effect of Public Procurement on innovative activities}

The role of demand-side factors has traditionally been underestimated in both economic theory and government policy, which largely focussed on supply-side factors enhancing innovation, as if markets were always capable of passively absorbing the innovations introduced (Edler and Georghiou, 2007). However, demand conditions have been shown to crucially influence the desirability and realization of inventions, while expected profitability resulting from the expansion of market demand represents the key stimulus to which inventive activities tend to respond (Kaldor, 1957; Schmookler, 1966; Mowery and Rosenberg, 1979; Kleinknecht and Verspagen, 1990). In this respect, previous empirical evidence showed that there was a positive relationship between demand and R\&D investments (Kleinknecht, 1996) and that innovations tend to show a pro-cyclic behaviour, with demand "Granger causing" innovation (Gerosky and Walters, 1995). According to Gerosky and Walters (1995), the economic explanation of this phenomenon is twofold. Firstly, markets have a limited ability to absorb new products in a given period. When demand expands, this capacity tends to grow, making the introduction of innovation more profitable. On the other hand, appropriability problems are involved in innovative activities, and the time firms have to profit from innovation is often limited. Thus, innovations are more likely to appear in periods characterised by a growing demand trend.

From a different perspective, user-producer interactions have been recognised as a further source of demand-pull effect on innovation (Von Hippel, 1986). Buyers can anticipate market demand by becoming early adopters and lead users, stimulating innovative activities for continuous improvement of both product and services. In so doing, they get involved in the innovation process and eventually become co-producers of user-driven innovations (Bresnahan, 2001; Malerba, 2007). As amply demonstrated by early contributions (Mowery and Rosenberg, 1979; Rothwell and Zegveld, 1981), PP can exert a significant influence on innovation activities with respect to all these channels (Cave and Frinking, 2003; Cabral et al. 2006), whether or not stimulation of innovations is an explicit goal of procurement activities pursued by governments (Uyarra and Flanagan, 2010). On the one hand, considering that (regular) PP accounts for a good part of the overall demand for goods and services, it can play a key role in enlarging the market for new goods and services, thus providing an incentive to invest in innovation. Public demand can create or consolidate a market, 
thus reducing uncertainty, favouring the development of a critical mass encouraging $R \& D$ investment and enabling dynamic increasing returns, especially in industries characterised by appreciable economies of scale, substantial R\&D sunk costs and high levels of uncertainty (see for instance Kaldor, 1981; Malerba, 2007; Chang and Andreoni, 2017). On the other hand, when innovation becomes an explicit goal of public procurement, as in the case of innovative procurement, public organisations can influence innovation directly by purchasing new goods and services. In this case, the public sector uses its own demand/need or acts as a catalyst for needs located outside the public agency specifically to induce innovation, often becoming a lead user and co-creator through user-producer interactions (Edquist et al. 2015).

While the literature has so far examined these issues mainly through qualitative (case-based) analyses or (more rarely) micro-level quantitative studies, the present paper aims, in the first place, to provide a large-scale empirical assessment of the role of PP in shaping innovation activities at the sectoral level for a large set of countries. In so doing, we are not able to distinguish between regular and innovative PP. However, we put forth a first (but still rough) attempt to empirically distinguish between the two PP types by using an ad-hoc PP innovation propensity index beside the standard PP indicator (in what follows, we provide a detailed of PP indicators adopted for the analysis).

\section{The role of import penetration}

The effectiveness of PP in spurring innovation activities also depends on the specific strategies that countries adopt regarding PP. Strategies concerning the degree of market openness can be of major importance, since if part of domestic public demand is intercepted by other countries' economies, the impact of public procurement on the internal production structure could be reduced. In this respect, procurement and innovation occur in space and the impacts of procurement on national (local) systems of innovation crucially depend on the spatial patterns of government procurement, on the degree of control over purchasing by the local and regional authorities, and on the extent to which benefits can be retained within a specific economic area through production linkages and knowledge spillovers (Porter, 1990; Uyarra and Flanagan, 2010).

Moreover, by giving preferential treatment to domestic firms in PP, governments can substantially reduce demand uncertainty and increase incentives to pursue innovative investment, as for instance was the case of the US aircraft industry, the Japanese mainframe computer industry, and the Finnish electronics industry (Chang and Andreoni, 2016). Finally, as preferentially acting on the proportions of local demand, PP can favour the role of increasing returns and learning effects in the generation of new knowledge, both within and outside individual firms (Arrow, 1962; Kaldor, 1966; Antonelli, 1999; Stiglitz and Greenwald, 2014; Andreoni and Scazzieri, 2014). 
These aspects appear to be of particular relevance if there are different degrees of international contestability of public demand in the various countries and for economies seriously distressed, as in the case of the EU periphery after the crisis (recall that countries like Italy and Spain lost around $20 \%$ of their manufacturing productive capacity between 2008 and 2013). For these reasons, when PP is used as an instrument of industrial policy to promote industrial renewal and the development of certain areas and technologies, types of enterprises - i.e. small and medium-sized enterprises - or specific geographic areas, governments tend to favor local companies so as to maximize the impact of public demand (see for instance Miyagiwa, 1991; Cohen, 2007; Peneder, 2017).

Policies aiming at ensuring the effectiveness of PP - from both the demand- and the supply-side perspective - can be considered policies of 'discriminatory procurement'. The discrimination occurs when governments uses PP to encourage local producers. Such discrimination may be explicit, as in the case of the "Buy American" clause in the US - the public purchase of foreign goods is in some cases avoided - or implicit, using price discrimination or taxes. Discrimination typically occurs, however, through tacit agreements between local producers and governments realized by contracting the time of publicizing the tender or imposing technical specifications favoring local producers (Lowinger 1976; Beviglia-Zampetti 1997, Kono and Rickard, 2014). From an economic point of view, protecting local companies by means of a discriminatory use of public procurement constitutes a barrier to international trade and is equivalent to imposing import restrictions (Brulhart and Trionfetti 2004; Trionfetti 2000). Historically, this tool has been widely used to protect domestic industry and promote the growth of the so-called 'national champions' (Cohen, 2007; Weiss and Thurbon, 2011).

It is worth noting the difference in the attitudes of the US and the EU towards the use of public procurement. The US, in fact, has always maintained a very extensive and stringent set of rules protecting the American market of public procurement while promoting American businesses (Wade, 2017). Ever since the Buy American Act of 1933, in fact, the US government has identified a core of public purchasing programs in which the federal government and national agencies are obliged to facilitate the purchase of goods and services produced locally. On the contrary, EU policies on public procurement have been explicitly designed to prevent any discrimination likely to favor domestic producers. The principle behind this approach is that the increased competition among suppliers - due to the opening up to international competition - enables efficiency gains in the production system, greater efficiency in public spending and thus welfare gains for the EU as a whole (Weiss and Thurbon, 2011, Ramboll Report, 2011). This attitude raises some concern because, on the one hand, the EU does not seem to be having much success in its ambition to open up the global market for public procurement significantly while, on the other hand, European 
companies appear to be penalized by different access rules on foreign markets of public procurement (Ramboll Report, 2011, European Commission, 2011).

Building on this argument the present paper seeks to test the hypothesis that import penetration of PP affects the relationship between public demand and industry innovativeness by reducing the potential of demand-pull effects of public procurement in triggering innovation activities and spurring industrial renewal.

\section{Data and descriptive evidence}

The empirical analysis is carried out over a panel of manufacturing industries for 24 countries observed over the period 1995-2012. The dataset provides a combination of Input-Output data on PP and of industry-level information on patents. Adopting the procedure proposed by Lybbert and Zolas (2014), we first derive information on patents in each industry for all the countries considered across the entire timespan selected (details on the procedure adopted to build the dataset are supplied below and in the Appendix). ${ }^{4}$ Secondly, we rely on the World Input Output Database (WIOD) to build industry-level variables on PP, import penetration on PP and exports (Timmer et al. 2015). Thirdly, we use data on R\&D expenditure drawn from the OECD ANBERD database to control for industries' investment in innovation activities.

Industries' innovative dynamics is captured by the sector performance on patents ${ }^{5}$. Since information on industries' patenting activities is not generally available, an imputation procedure to break country-level information down to the industry-level is needed. In this respect, significant advances have been made thanks to the imputation technique recently elaborated by Lybbert and Zolas (2014). ${ }^{6}$ We follow their approach ${ }^{7}$, obtaining a 15 -year-long panel of industries' patenting activities. Moreover, we compute patent stock using a standard inventory methods accounting for

\footnotetext{
${ }^{4}$ Patent data refer to European Patent Office (EPO) applications carried out by the considered countries between 1995 and 2009.

${ }^{5}$ We recognize that the use of patent data presents several drawbacks: among others, the distribution of patents across firms and sectors is highly skewed, there is a large variance in patent quality and, most importantly, only a fraction of innovations is patented (Griliches, 1990; Jaffe and Trajtenberg, 2002). However, in order to build a sufficiently long panel data set on innovation performance of industries we believe this was the best available option.

${ }^{6}$ As Lybbert and Zolas (2014) point out, "While patent data often serve as useful proxies for technological change and diffusion, fully exploiting patent data in economic analyses would require that patents be linked to economic activity at a level of disaggregation that allows for different technological, industrial and spatial patterns. Such a detailed link between technological and economic activity would further improve our assessment of policies that aim to promote innovation, as well as assess the relationship between technological change and economic development” (pp. 530). In light of this, further attempts for industry-level linkages that associate patents and economic data based on the domain of goods and services they represent is strongly required for enrich the economic analysis

7 The Lybbert and Zolas (2014)'s imputation procedure is based on an Algorithmic Links with Probabilities (ALP) applied to patents' content descriptions. Focusing on the correspondence between patent contents and sectors characteristics this procedure allows matching, with a significant level of precision, patents identified according to the IPC classification; and 2-digit industries.
} 
the depreciation of the knowledge-stock (see the Appendix for illustration of the methodology adopted). Once patents are assigned to industrial sectors according to the methodology of Lybbert and Zolas (2014), the three data sources - namely the WIOD, the OECD ANBERD and the EPO patent database - are merged together. To this end, the ISIC classification in accordance with the NACE information is used to match patents with PP, import penetration, export and R\&D data. In table 1, we provide the list of variables included in the analysis.

Table 1. List of variables and sources

\begin{tabular}{lcc}
\hline \multicolumn{1}{c}{ Variable } & Unit & Source \\
\hline Patents filed at the EPO & Absolute value & EPO \\
Public procurement $(P P)$ & Millions of euros (real values) & WIOD \\
$\begin{array}{l}\text { Innovative PP propensity index } \\
\text { Import penetration } \text { on public } \\
\text { procurement }\end{array}$ & Millions of euros (real values) & Share \\
$\begin{array}{l}\text { Export over value added } \\
\text { R\&D expenditure }\end{array}$ & Share & WIOD \\
\hline
\end{tabular}

The variable capturing industry-level PP is computed as the sum of goods and services - both intermediate and final - purchased by the public sector from each 2-digit industry. In so doing, we follow the strategy adopted by Messerlin and Mirodout (2012). We add to the information on government expenditure on goods and services the purchases made by the following industries: 'electricity, gas and water supply' (100\%), 'post and telecommunications' (50\%), 'public administrations and defence, compulsory social security' (100\%), 'education' (100\%) and 'health and social work' (100\%). Therefore, for each sector $i$, country $j$ and year $t$, the PP variable gives the value of goods and services purchased by the government of the country concerned $\mathrm{j}$ from that sector i (see equation 2 below).

As argued in the literature background section, and at length by Edquist (2015), the PP proinnovative stance may vary considerably according to the 'type' of PP taken into consideration. In particular, it is worth distinguishing between regular and innovation-related $P P$, with the latter in the sense of government purchases of goods and services that explicitly promote innovation. Edquist (2015: p.6) refers to 'regular PP' as 'the purchase of pens, paper, towels, trains, telecommunication services, cars, etc.". In these cases, "innovations may occur spontaneously". On the contrary, innovation-related PP, in turn, concerns government purchases of goods and services that do not exist at the time of the order.

Though we do not have specific information on innovative PP, in order to capture the potential different propensity of governments toward innovation procurement, we build an indicator - i.e. the innovative PP propensity index - by weighting information on sectoral PP by the country-level share of public expenditure devoted to $R \& D$, as reported by Eurostat. Albeit simple, this indicator allows for combination of, on one hand, data on the relevance and dynamics of PP in each sector 
and country, and, on the other, information on the priority each government attributes to innovation. Relying on this indicator, we test whether, and if so to what extent, the PP demand-pull effect is affected by governments' innovation propensity. Formally, the innovation PP propensity index can be represented as follows (1):

$$
I P P_{i j t}=\left(G_{i j t}+\sum_{i j t} G_{k}^{S E C T}\right) * R \& D S H_{j t}
$$

where, for each sector-country-year triple, the innovative PP index is equal to the sectoral PP - i.e. the sum of government purchases of final goods and services from a certain sector i plus the sum of intermediate goods purchased from the same sector by the $\mathrm{k}$ industries $(\mathrm{k}=1, \ldots, 5)$ - weighted by the share of public expenditure for R\&D activities out of the total.

The variable identifying the degree of import penetration of $P P$ is calculated as the share of (domestic) public procurement to sector $\mathrm{j}$ which is captured by foreign producers (Ramboll Report, 2011; Messerlin and Mirodout, 2012). For instance, the share of import penetration of the Italian motor vehicle industry is equal to the share of government purchases of motor vehicles produced abroad in the total public procurement directed towards the motor vehicle industry. The same holds for all the manufacturing sectors of each country.

The import penetration indicator (2) is computed as:

$$
I m p_{-} \text {pen }_{i j t}=\frac{\left(\sum_{k}^{k=1, \ldots, n ; k \neq j} G_{i k t}+\sum_{k}^{k=1, \ldots, n ; k \neq j} G_{i k t}^{S E C T}\right)}{\text { Tot_PP }_{i j t}}
$$

where, the numerator is the sum of intermediate and final goods imported by the government of country $\mathrm{j}$ from a certain sector $\mathrm{i}$; the denominator is total public demand by the government of country $\mathrm{j}$ directed towards sector $\mathrm{i}$ - i.e. the first term on the RHS of equation (1). Hence, (2) measures how much PP - for each country $\mathrm{j}$ and sector $\mathrm{i}$ - directed towards a certain sector relies on foreign producers rather than on domestic ones.

\section{The dynamics of public procurement and import penetration}

As a preliminary step, we analyze the dynamics of PP and import penetration on PP between 1995 and 2011. Over the considered time span, the share of PP on total aggregate demand increases in Europe, the US and Japan (figures 1 and 2). ${ }^{8}$

\footnotetext{
${ }^{8}$ The time horizon coincides with the one used for the econometric analysis. In the descriptive analysis we include all EU27 economies while in the econometric one some EU countries are missing due to the lack of data on patents. The
} 


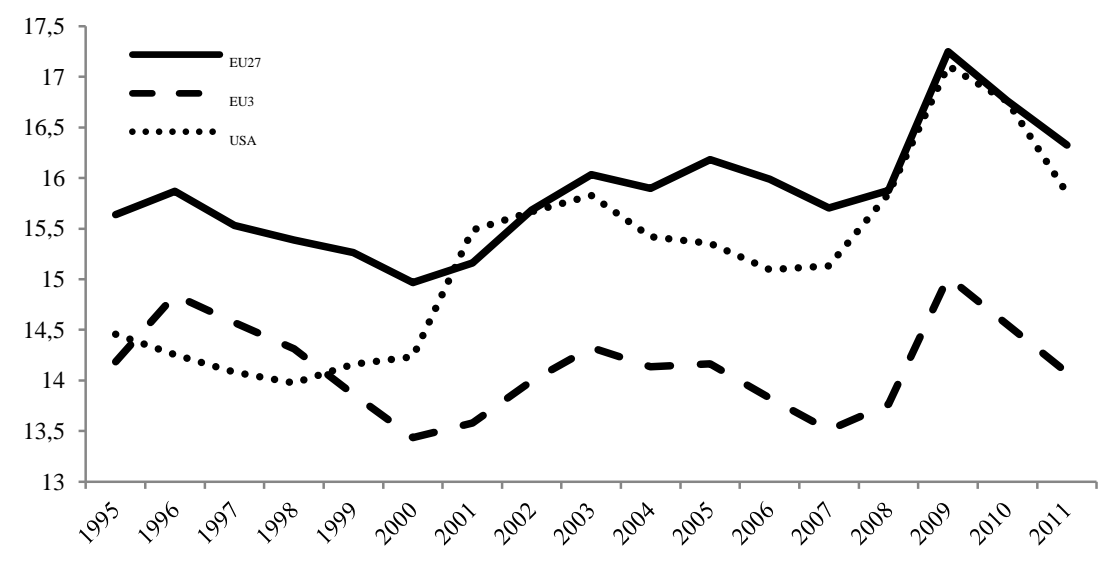

Source: our elaboration on WIOD data

However, some relevant elements of heterogeneity are detectable. During the 1995-2000 period, PP' share declines in Europe (and in a more pronounced way in the EU3 aggregate including France, Germany and Italy); while it increases in Japan and, to a lower extent, in the US. Along the 2000s, the EU27's PP share lies above both the US and the Japanese one. Nevertheless, the explosion of the 2008 crisis coincides with a sharp drop of PP shares in all the considered countries with Japan being the only one showing a slight recovery after 2010.

Figure 2. Share of public demand on total demand in EU27, EU3 (Ger, It and Fr) and Japan

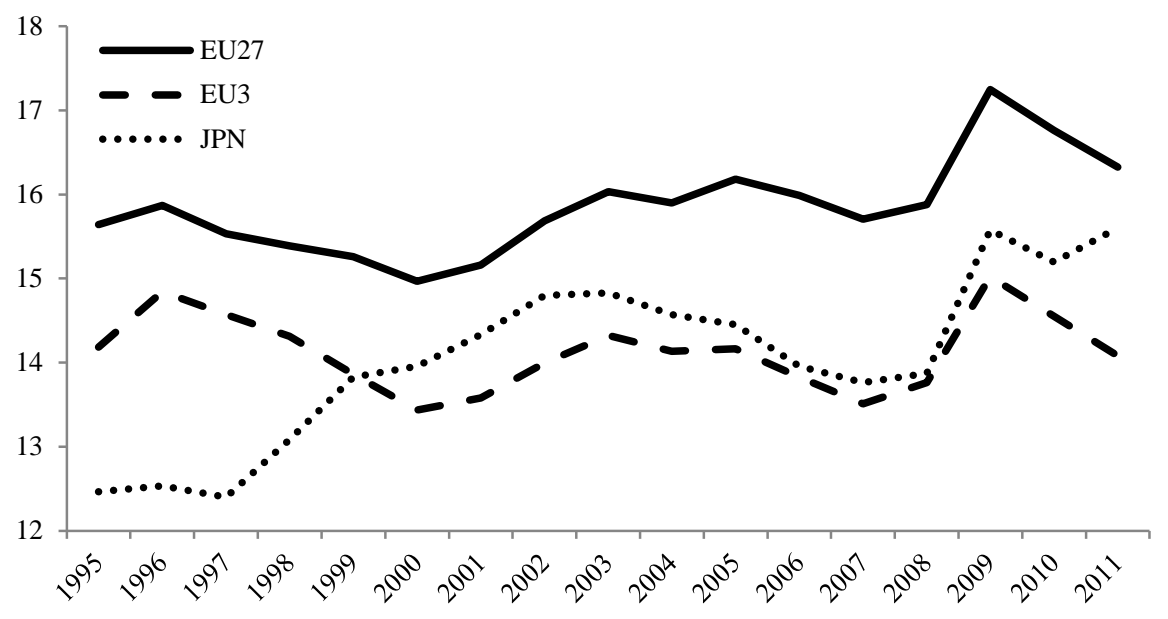

Source: our elaboration on WIOD data

Moving to the dynamics of import penetration (figures 3-4), it emerges a watershed around the year 2000. In all the economies taken into consideration, this year coincides with the start of a trend of 
increasing import penetration on PP continuing until the crisis (and in the European case even afterwards). The discontinuity observed around the 2000 may be linked to the beginning of a phase during which the intensity of trade and production globalization skyrockets following, for example, events such as China joining the WTO. Comparatively, the US show the highest degree of import penetration with Europe remaining a little behind. The degree of import penetration on PP, in turn, is significantly lower in Japan in the early 2000s but tends to converge to the US and EU27 levels around 2008 .

Figure 3. Import penetration on public procurement in EU27, EU3 (Ger, It and Fr) and USA

1995-2011

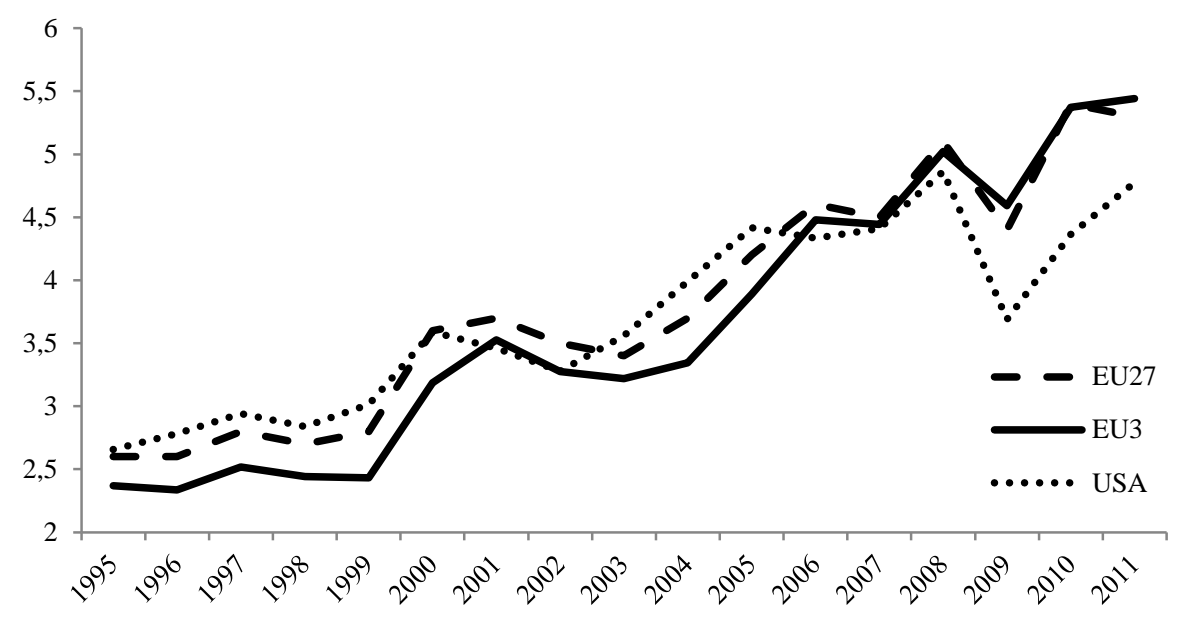

Source: our elaboration on WIOD data

After 2008, the dynamics of import penetration on PP starts diverging. While the EU27 and the EU3 are continuing in a trend of increasing import penetration on public procurement, in the US there has been a sharp fall that stops, with a gradual recovery, towards the end of 2009. During the crisis, thus, the degree of openness of public procurement in Europe and in the US starts diverging substantially. This evidence can be associated with the effects of 'protectionist' measures - i.e. the 'Buy American' act - aimed at protecting public procurement and put forth in the US early after the crisis explosion. A reinforced 'buy American' would seem to explain, at least in part, the sudden divergence in the dynamics of import penetration depicted in figure 4.

A dynamics of divergence characterizes also the trend of import penetration observed in Japan as opposed to the EU27 and EU3 ones. The comparison between Europe and Japan shows that the latter lies well below the two EU aggregates for the whole period considered and, in particular, from the crisis onwards. This is possibly due, on the one hand, to the traditional introversion of the 
Japanese economy, as testified also by the lower degree of import penetration characterizing the 1995-2007 phase. $^{9}$

Figure 4. Import penetration on public procurement in EU27, EU3 (Ger, It and Fr) and Japan

1995-2011

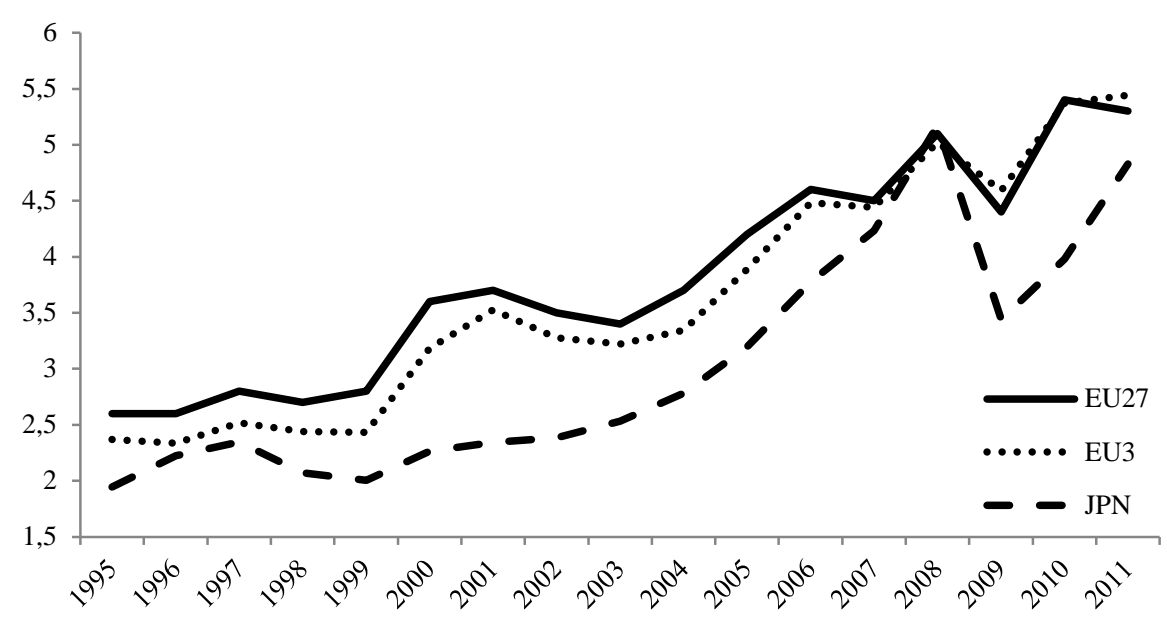

Source: our elaboration on WIOD data

Similarly to what has been shown concerning the US, on the other hand, the marked reduction of import penetration observable after 2008 can be due to the adoption of a 'protectionist' strategy put forth by the Japanese government as a response to the drop in aggregate demand following the crisis.

Such descriptive evidence confirms the relevance of PP as a major component of effective demand and suggests that different strategies are adopted by different countries in terms of its openness degree to international markets. The following econometric analysis is then designed to identify the role of these variables in shaping industries' innovation activities.

\section{Model, econometric strategy and results}

\section{The model}

The relationship between PP and industries innovative dynamics and of the moderating role exerted by import penetration are investigated relying on the following econometric specification (3):

$$
P A T_{i j t}=\beta_{1} * P P_{i j t-1}+\beta_{2} * I P P_{i j t-1}+\beta_{3} * I M P_{P P i j t-1}+\beta_{4} *\left(I M P_{P P i j t-1} * P P_{i j t-1}\right)+
$$

\footnotetext{
${ }^{9}$ The Japanese economy is characterized by a relatively lower propensity towards production outsourcing and offshoring as compared to the EU and the US. This element tends to relatively reduce the purchase of goods and services from abroad to meet public demand.
} 


$$
\beta_{5} *\left(I M P_{P P i j t-1} * I P P_{i j t-1}\right)+\beta_{6} * X_{i j t-1}+\varepsilon_{i j t}
$$

where $\mathrm{i}$ stands for sector, $\mathrm{j}$ for country and $\mathrm{t}$ for time. The dependent variable $P A T_{i j t}$ is the patent stock - we considered the stock of patents at time $t$ accounting for both new patents and depreciation of the knowledge stock. $P P_{i j t-1}$ is the public procurement variable providing information on public procurement directed to each sector $\mathrm{i}$ at time $\mathrm{t}-1$ while $I P P_{i j t-1}$ is the PP innovation propensity index described above. The degree of import penetration on PP is identified by $I M P_{P P_{i j t-1}}$ and the latter is than interacted with both $P P_{i j t-1}$ and $I P P_{i j t-1}$. The term $X_{i j t-1}$, in turn, includes a set of controls such as the lagged change in sectoral R\&D expenditure and lagged export intensity - i.e. gross exports on sectoral value added - while $\varepsilon_{i j t}$ is the standard error term.

The coefficients $\beta_{1}$ and $\beta_{2}$ identify, respectively, the association between PP and the 'innovationaugmented' PP indicator, on one hand, and the sectoral patent stock, on the other. Finally, $\beta_{4}$ and $\beta_{5}$ capture the (average) additional effect that import penetration has on the PP-innovation relationship. The use of lags has both theoretical and methodological reasons. Theoretically, we argue that the potential effects of PP on industries' innovation dynamics - as well as the effect of the other demand-pull (export intensity) and technology-push (change in R\&D expenditure) elements included in (3) - come into operation only after a time lag. From a methodological standpoint, using lagged regressors mitigates the risk of simultaneity-related endogeneity.

The specification in (3) constitutes an enhancement with respect to the previous models exploring the determinants of innovation in industries. In particular, we follow the contributions examining jointly the impact on industries' innovative performance in technology-push and demand-pull factors - see, among the others, Crespi and Pianta (2007), Guarascio et al. (2015, 2016) and Guarascio and Pianta (2016), by adding variables that explicitly account for PP and import penetration of PP.

The model builds on the hypothesis that aggregate demand and, particularly, PP are important drivers of technological change and innovation (Edquist, 2015; Mazzucato et al. 2015). Following the demand-pull perspective, innovation is developed when companies anticipate significant demand flows. According to this view, the introduction of innovations is supported by sciencerelated developments and is triggered by relative prices in a feasible production set. The magnitude of the demand-pull effect may, however, vary according to the type of demand flow faced by firms and industries. In particular, authors like Bogliacino et al. (2013) and Guarascio et al. (2016) identify exports as a crucial driver of product innovation in European industries. In Pasinetti (1981)' work, in turn, the development of innovations is seen as embedded in a process of continuous changes of the industrial structure, fundamentally driven by demand. 
Within this process, the generation of labour-enhancing process innovations - i.e. the kind of innovations that Pasinetti (1981) recognizes as fundamental to sustain employment and income growth by overcoming coordination problems between individual and collective choices - cannot be achieved without continuous and sustained demand flows. In this context, the nature of these demand flows - i.e. distinguishing between private, public, domestic demand or exports as well as between consumption and investments - and the technological characteristics of industries receiving such flows are of primary importance. As regards the first element, the powerful role of public demand - and, in particular, of PP - as innovation driver is repeatedly stressed by Mazzucato (2016), who argues that public investments are absolutely essential in forming and creating new technological opportunities and market landscapes.

In this respect, the implementation of public investment programs designed to solve specific societal problems - i.e. societal challenges such as climate change, obesity, ageing, etc. - tend to mobilize knowledge-intensive lines of production, stimulating company innovation and generating economy-wide technological spillovers. On the other hand, orientation of public investments and PP towards high-tech sectors may strengthen such industries, reinforcing their economic and innovative dynamics with benefits unfolding throughout the economy. From this point of view, and in line with the arguments presented in Mazzucato (2016), PP represents a key (selective) industrial policy tool having among its major objectives the promotion of innovation and technological upgrading. Concerning the role of import penetration, the question is: does opening up PP to foreign competition affect the capacity of public demand to stimulate innovation? As already argued, we explore these relationships having the opportunity to test the latter, first considering the full set of countries under analysis, and secondly comparing the PP-import penetration-innovation nexus in Europe - PP being open to foreign competition both before and after the 2008 crisis - and in the US - where a restriction on foreign competition in PP, the 'Buy American' Act, was introduced as from 2008.

The key hypothesis tested by estimating the model in (3) can be summarized as follows. To begin with, we test whether PP is positively associated with industries' patenting activities, controlling for both technology-push (R\&D efforts) and demand-pull factors (export intensity). Second, we verify whether the relationship between PP and patents changes when PP is distinguished between a general measure and the PP innovation propensity index (see above for a description of the index). Third, we investigate whether, and if so to what extent, a relatively more intense import penetration of PP affects the relationship between the latter and industries' innovativeness. Having analyzed the general relationships - i.e. estimating the model over the full sample of countries and industries included in the analysis -, we explore two different levels of heterogeneity. Focusing on country- 
level heterogeneity, we test whether the relations emerging from the full sample model vary, estimating the same model on European industries only. Turning, then, to the technological heterogeneity, we test whether the PP-import penetration-patents nexus changes when distinction is made between high and low-tech industries.

\section{Econometric strategy and results}

The use of patent data as proxies of the innovative activity implies that we have to deal with count variables, that is, variables with non-negative integer values. Econometric models specifically designed for this kind of variable are the Poisson Regression Model (PRM) and the Negative Binomial Regression Model (NBRM). Given the characteristics of our data and the limited number of zeros in our count variables, we analyse the relation between PP and industries patenting activities relying on the PRM. ${ }^{10}$ Poisson regression fits models of the number of occurrences (counts) of an event by assuming that the dependent variable has a Poisson distribution. Moreover, it assumes that the logarithm of its expected value can be modeled by a linear combination of unknown parameters. To control for industry-level heterogeneity, we exploit the panel structure of our data by implementing the Poisson fixed effects estimator. ${ }^{11}$ In this way, we limit the risk that the detected relationships are driven by industry or country-specific idiosyncratic elements. Finally, in order to soften potential endogeneity biases and ensure estimations consistency, we include all regressors at their first lag.

All the estimations are performed adopting a stepwise procedure based on four different specifications. In the first specification, industries patents are regressed against the annual change (expressed as logarithmic difference) in $R \& D$ expenditure and export intensity (exports over value added) only. The second includes the lagged change in PP (logarithmic difference) testing the degree of correlation between patenting and public demand. The third specification includes both PP and PP innovation propensity index to check for potential heterogeneity between the two. Finally, we test the full specification having, on the right hand side, change in R\&D expenditure,

\footnotetext{
${ }^{10}$ This is the natural starting point for an analysis of count data but it may be biased by an excess in zeros and an overdispersion problem. In many applications, the model underestimates the probability of a zero count and low counts in general. In addition, the equidispersion assumption of the Poisson model, the equality of the conditional mean and the conditional variance is commonly violated. Real variables are often overdispersed, that is, the variance exceeds the mean. The major disadvantage in the presence of overdispersion is that estimates are inefficient with the standard errors biased downward, resulting in spuriously large z-values and small p-values (Cameron and Trivedi, 1998). In these cases, the NBRM, which addresses the failure of the PRM by introducing unobserved heterogeneity across the Poisson means, could be used. In our case, however, the reduced number of zeros among the dependent variables observations of the dependent variable and the results of tests conducted to this purpose are in favor of the use of the PRM.

${ }^{11}$ The Poisson fixed effect estimator conditions the probability of the counts for each group on the sum of the counts for the group. The maximum likelihood method is used to estimate the model parameters.
} 
export intensity, PP, PP innovation propensity index, degree of import penetration and the interaction between the two PP indicators and the import penetration variable.

Table 3 reports the result of the full sample model. Industries patenting activities show a significant association with both export intensity and $\mathrm{R} \& \mathrm{D}$ expenditure, testifying the joint action of technology-push and demand-pull factors as in Guarascio et al. (2016). The strongest result regard the PP-innovation nexus. Looking at sign and significance of the PP coefficients, it emerges that industries characterized by a relatively more intense PP flows have also a more intense innovative dynamics in terms of patents. Such positive association between PP and industries patenting activities is confirmed by the coefficient associated to the PP innovation propensity index.

Interestingly, when the degree of import penetration on PP is taken into account, firstly it emerges that there is not a direct effect on innovation exerted by PP openness, suggesting that increasing international competition in PP does not spur innovative activities of domestic industries. On the contrary, in line with the hypothesis put forth above, a high degree of import penetration exerts a (negative) moderating effect on the PP-innovation relation, as testified by the coefficient associated to the PP-import penetration interaction term. No significant effects are registered with respect to the interaction between import penetration and the PP innovation propensity index.

Table 3. Fixed effects Poisson estimations - Patents stock vs public procurement, innovative public procurement, import penetration, interaction term and controls (full sample model)

\begin{tabular}{|c|c|c|c|c|}
\hline & (1) & (2) & (3) & (4) \\
\hline Export intensity (first lag) & $\begin{array}{c}0.00716 * * * \\
(0.00162)\end{array}$ & $\begin{array}{c}0.00672 * * * \\
(0.00159)\end{array}$ & $\begin{array}{c}0.00649 * * * \\
(0.00163)\end{array}$ & $\begin{array}{l}0.00549 * * \\
(0.00205)\end{array}$ \\
\hline$\Delta \mathrm{R} \& \mathrm{D}$ expenditure (first lag) & $\begin{array}{c}0.0558 \\
(0.0492)\end{array}$ & $\begin{array}{c}0.0526 \\
(0.0493)\end{array}$ & $\begin{array}{l}0.106^{* *} \\
(0.0331)\end{array}$ & $\begin{array}{c}0.102^{* * *} \\
(0.0308)\end{array}$ \\
\hline$\Delta$ Public procurement (first lag) & & $\begin{array}{l}0.122 * * * \\
(0.0352)\end{array}$ & $\begin{array}{l}0.124 * * * \\
(0.0341)\end{array}$ & $\begin{array}{l}0.264 * * * \\
(0.0539)\end{array}$ \\
\hline $\begin{array}{l}\Delta \text { PP Innovation propensity Index } \\
\text { (first lag) }\end{array}$ & & & $\begin{array}{c}0.0916^{* *} \\
(0.0293)\end{array}$ & $\begin{array}{l}0.113 * * \\
(0.0388)\end{array}$ \\
\hline Import penetration on PP (first lag) & & & & $\begin{array}{c}0.000912 \\
(0.000963)\end{array}$ \\
\hline $\begin{array}{l}\Delta \text { Public procurement } * \text { import } \\
\text { penetration (first lag) }\end{array}$ & & & & $\begin{array}{c}-0.00304 * * * \\
(0.000770)\end{array}$ \\
\hline $\begin{array}{l}\Delta \text { PP Innovation propensity Index* } \\
\text { import penetration (first lag) }\end{array}$ & & & & $\begin{array}{c}-0.000534 \\
(0.00105)\end{array}$ \\
\hline Observations & 6976 & 6974 & 6210 & 6210 \\
\hline
\end{tabular}


According to the full sample model results, thus, PP exerts a significantly and strongly positive impact on industries innovative dynamics. In this respect, PP operates beside standard technology push (industries R\&D expenditure) and demand-pull factors (exports) yet remaining strongly significant from a statistical point of view. Interestingly, no significant difference between PP and the PP innovation propensity index is registered. On the contrary, both variables have a strong association with the dynamics of patents. In turn, those industries facing a domestic public sector that relies comparatively more on foreign producers are characterized by a relatively weaker innovative dynamics in terms of patents.

As discussed before, different approaches to PP as well as different degree of openness of PP to foreign producers may significantly impact on the public demand-innovation relation. Trying to capture potential heterogeneities between Europe and the other countries included in our sample i.e. Japan, Korea, Russia, Turkey and the US -, we estimate the model in (3) on the sub-sample of European industries. $^{12}$

Table 4. Fixed effects Poisson estimations - Patents stock vs public procurement, innovative public procurement, import penetration, interaction term and controls (European economies only)

\begin{tabular}{|c|c|c|c|c|}
\hline & $(1)$ & (2) & (3) & (4) \\
\hline Export intensity (first lag) & $\begin{array}{c}0.00762 * * * \\
(0.00162)\end{array}$ & $\begin{array}{c}0.00721^{* * *} \\
(0.00160)\end{array}$ & $\begin{array}{c}0.00683 * * * \\
(0.00162)\end{array}$ & $\begin{array}{c}0.00532 * * * \\
(0.00155)\end{array}$ \\
\hline$\Delta \mathrm{R} \& \mathrm{D}$ expenditure (first lag) & $\begin{array}{c}0.0432 \\
(0.0286)\end{array}$ & $\begin{array}{c}0.0366 \\
(0.0278)\end{array}$ & $\begin{array}{l}0.0360 \\
(0.0275)\end{array}$ & $\begin{array}{c}0.0331 \\
(0.0273)\end{array}$ \\
\hline$\Delta$ Public procurement (first lag) & & $\begin{array}{r}0.110^{* * *} \\
(0.0269)\end{array}$ & $\begin{array}{r}0.104 * * * \\
(0.0253)\end{array}$ & $\begin{array}{l}0.231^{* * *} \\
(0.0378)\end{array}$ \\
\hline $\begin{array}{l}\Delta \text { PP Innovation propensity Index (first } \\
\text { lag) }\end{array}$ & & & $\begin{array}{l}0.0678 * * \\
(0.0257)\end{array}$ & $\begin{array}{c}0.165 * * * \\
(0.0431)\end{array}$ \\
\hline Import penetration on PP (first lag) & & & & $\begin{array}{c}0.00159 \\
(0.00120)\end{array}$ \\
\hline $\begin{array}{l}\Delta \text { Public procurement } * \text { import } \\
\text { penetration (first lag) }\end{array}$ & & & & $\begin{array}{l}-0.00232 * * \\
(0.000754)\end{array}$ \\
\hline $\begin{array}{l}\Delta \text { PP Innovation propensity Index* import } \\
\text { penetration (first lag) }\end{array}$ & & & & $\begin{array}{l}-0.00226^{*} \\
(0.000899)\end{array}$ \\
\hline Observations & 4881 & 4880 & 4880 & 4880 \\
\hline
\end{tabular}

Standard errors in parentheses

$* \mathrm{p}<0.05, * * \mathrm{p}<0.01, * * * \mathrm{p}<0.001$

\footnotetext{
${ }^{12}$ The countries included in this subsample are: Austria (AT), Belgium (BE), Czech Republic (CZE), Germany (GER), Spain (SP), Finland (FIN), France (FR), United Kingdom (UK), Greece (GRC), Hungary (HUN), Ireland (IRE), Italy (IT), the Netherlands (NE), Poland (PO), Portugal (PT), Romania (RO), Slovakia (SK), Slovenia (SV), Sweden (SWE) covering almost all the EU27 economy.
} 
The European test shows both similarities and differences with respect to the full sample model. First of all, the positive relation between PP and industries innovation is confirmed. Even in Europe, industries facing relatively more intense PP flows are those showing a relatively larger patent stock. This result holds looking at both the general PP variable as well as the PP innovation propensity index. The major difference regards the role of import penetration on PP. Differently to the previous estimation, the moderating effect of import penetration is now detected with respect to both the interaction terms. This evidence suggests that a high degree of import penetration has a moderating (negative) effect on the PP-innovation nexus for both the European economies characterized by a public sector with a strong innovation propensity, as well as for those with a comparatively weaker innovation propensity. Regarding the other controls, the positive association between exports and patents is confirmed; while the same do not holds for the change in $R \& D$ intensity that, on the contrary, is always not significant.

Overall, the test on European industries provides support to the hypothesis that PP is a key driver of industries innovation. This is true irrespectively from the variable used to measure PP. When it comes to import penetration, however, the latter seems to penalize the pro-innovative effect of public demand with respect to both PP and PP innovation propensity index. In this respect, the penalizing effect of import penetration on the PP-innovation nexus seems to operate in spite of the differences - in terms of governments' relative innovation propensity - characterizing European economies.

\section{The role of industries technological heterogeneity}

As already argued, the relationship between PP and industries innovative dynamics may vary substantially according to industries technological characteristics. Following Pasinetti (1981) and Mazzucato (2016)'s insights, we test whether the association detected pooling all industries is reshaped when low and high-tech sectors are separately analyzed. The main hypothesis is that the positive association between PP and industries innovative activities is stronger for those sectors characterized by a relatively more intense use of knowledge and technology. The distinction between the two industry groups is made relying on the revised Pavitt taxonomy recently proposed by Bogliacino and Pianta (2016). Following the grouping based on this taxonomy and proposed in Guarascio et al. (2016), we include in the high-tech cluster the industries belonging to the Science Based (SB) and Supplier Specialized (SS) Pavitt's groups - i.e. industries identified as those that more intensively rely on innovation. Contrarily, we include in the low-tech cluster the industries belonging to the Supplier Dominated (SD) and Scale Intensive (SI) groups. According to the Pavitt taxnomy's rationale, SB and SS industries are characterized by a relatively more intense use of 
knowledge and technology in their production process as compared to other sectors; rely mostly on high tech intermediate inputs; and their openness to the foreign market is also remarkable.

Table 5. Fixed effects Poisson estimations - Patents stock vs public procurement, innovative public procurement, import penetration, interaction term and controls (Science Based and Specialized Supplier industries)

\begin{tabular}{|c|c|c|c|c|}
\hline & (1) & (2) & (3) & (4) \\
\hline \multirow[t]{2}{*}{ Export intensity (first lag) } & $0.00957 * *$ & $0.00871 * *$ & $0.00845 * *$ & $0.00953 *$ \\
\hline & $(0.00320)$ & $(0.00312)$ & $(0.00311)$ & $(0.00466)$ \\
\hline \multirow[t]{2}{*}{$\Delta \mathrm{R} \& \mathrm{D}$ expenditure (first lag) } & -0.00204 & -0.0235 & $0.284 *$ & $0.292 * *$ \\
\hline & $(0.200)$ & $(0.193)$ & $(0.118)$ & $(0.112)$ \\
\hline \multirow[t]{2}{*}{$\Delta$ Public procurement (first lag) } & & $0.237 * * *$ & $0.216^{* *}$ & $0.562 * * *$ \\
\hline & & $(0.0714)$ & $(0.0722)$ & $(0.122)$ \\
\hline \multirow{3}{*}{$\begin{array}{l}\Delta \text { PP Innovation propensity Index (first } \\
\text { lag) }\end{array}$} & & & & \\
\hline & & & $0.142 *$ & $0.280 *$ \\
\hline & & & $(0.0639)$ & $(0.120)$ \\
\hline \multirow[t]{2}{*}{ Import penetration on PP (first lag) } & & & & -0.000362 \\
\hline & & & & $(0.00238)$ \\
\hline \multirow[t]{2}{*}{$\begin{array}{l}\Delta \text { Public procurement } * \text { import } \\
\text { penetration (first lag) }\end{array}$} & & & & $-0.00733 * * *$ \\
\hline & & & & $(0.00215)$ \\
\hline \multirow[t]{2}{*}{$\begin{array}{l}\Delta \text { PP Innovation propensity Index } * \text { import } \\
\text { penetration (first lag) }\end{array}$} & & & & -0.00344 \\
\hline & & & & $(0.00225)$ \\
\hline Observations & 1591 & 1591 & 1415 & 1415 \\
\hline
\end{tabular}

Standard errors in parentheses

$* \mathrm{p}<0.05, * * \mathrm{p}<0.01, * * * \mathrm{p}<0.001$

Conversely, SI and SD industries are characterized by a comparatively lower propensity towards innovation and by an intensive use of low tech inputs originating principally from the domestic market. The full list of industries included in the Bogliacino and Pianta (2016)'s revised Pavitt taxonomy is reported in the Appendix.

The test on high tech industries (table 5) displays a picture that significantly overlaps what emerged estimating the full sample model (table 3). As before, industries patenting activities seems to be supported by both technology-push and demand-pull drivers. Looking at columns (3) and (4), in fact, it can be noted that the variables capturing industries export intensity and R\&D efforts are both positively and significantly associated with the dynamics of patents. As expected, PP has a strong impact on SB and SS' industries' patents stock. Contrarily, the PP innovation propensity index shows a weaker (albeit positive) statistical association with the dependent variable. Remarkably, the moderating effect of import penetration affects also the sub-cluster of high-tech industries: sign and significance of the coefficient associated with the PP-import penetration interaction term (column 4) points to a negative and significant moderating effect of import penetration. 
Table 6. Fixed effects Poisson estimations - Patents stock vs public procurement, innovative public procurement, import penetration, interaction term and controls (Scale Intensive and Supplier Dominated industries)

\begin{tabular}{|c|c|c|c|c|}
\hline & (1) & (2) & (3) & (4) \\
\hline Export intensity (first lag) & $\begin{array}{c}0.00526 * * * \\
(0.00153)\end{array}$ & $\begin{array}{l}0.00496 * * \\
(0.00151)\end{array}$ & $\begin{array}{l}0.00456 * * \\
(0.00162)\end{array}$ & $\begin{array}{c}0.00321 \\
(0.00193)\end{array}$ \\
\hline$\Delta \mathrm{R} \& \mathrm{D}$ expenditure (first lag) & $\begin{array}{l}0.0683 * \\
(0.0286)\end{array}$ & $\begin{array}{l}0.0674 * \\
(0.0295)\end{array}$ & $\begin{array}{l}0.0689 * \\
(0.0313)\end{array}$ & $\begin{array}{l}0.0670^{*} \\
(0.0292)\end{array}$ \\
\hline$\Delta$ Public procurement (first lag) & & $\begin{array}{l}0.0830 * \\
(0.0328)\end{array}$ & $\begin{array}{l}0.0894 * * \\
(0.0327)\end{array}$ & $\begin{array}{l}0.195 * * * \\
(0.0448)\end{array}$ \\
\hline $\begin{array}{l}\Delta \text { PP Innovation propensity Index (first } \\
\text { lag) }\end{array}$ & & & $\begin{array}{l}0.0767 * \\
(0.0320)\end{array}$ & $\begin{array}{l}0.0890 * \\
(0.0407)\end{array}$ \\
\hline Import penetration on PP (first lag) & & & & $\begin{array}{c}0.00136 \\
(0.000911)\end{array}$ \\
\hline $\begin{array}{l}\Delta \text { Public procurement } * \text { import } \\
\text { penetration (first lag) }\end{array}$ & & & & $\begin{array}{r}-0.00230 * * \\
(0.000714)\end{array}$ \\
\hline $\begin{array}{l}\triangle \text { PP Innovation propensity Index* import } \\
\text { penetration (first lag) }\end{array}$ & & & & $\begin{array}{r}-0.000342 \\
(0.00123)\end{array}$ \\
\hline Observations & 5385 & 5383 & 4795 & 4795 \\
\hline $\begin{array}{l}\text { Standard errors in parentheses } \\
* \mathrm{p}<0.05, * * \mathrm{p}<0.01, * * * \mathrm{p}<0.001\end{array}$ & & & & \\
\hline
\end{tabular}

The final test regards low-tech industries (table 6). The relevance of R\&D efforts and exports as explanatory factors is almost confirmed. Interestingly enough, the variable capturing industries export intensity lose significance when the model is fully specified (column 4). This finding is in line with the comparatively lower degree of internationalization characterizing this group of sectors as opposed to the SB and SS ones. Moving to the role of PP, the latter exerts its positive and significant impact on patents also in SD and SI industries. This result is particularly important since it points to a potential 'upgrading effect' of PP. That is, the presence of relevant PP flows seems to stimulate the development of innovations even in industries traditionally less prone to this kind of activities. In this sense, one may argue that a large-scale and well targeted PP can not only work on the 'intensive margin' - i.e. pushing innovative activities of those industries that are already characterized by the introduction of new products, new processes and patents; but also on the extensive one - i.e. favoring the upgrading of low-tech industries and the diffusion of innovative activities among firms populating the SD and SI groups. The moderating effect of import penetration, finally, seems to be stronger also for low-tech industries. 


\section{Conclusions}

Nine years after the explosion of the 2008 crisis, industrial policy is coming back to the fore as a key action to promote growth and development. This revival interrupts thirty years or radical neglect, at least if industrial policy is intended as direct and selective interventions aimed at creating and steering new productions and markets (Chang and Andreoni, 2016; Mazzucato, 2016). A set of 'old-style' industrial policy instruments are now back in the policy makers toolbox to spur firms, industries and, ultimately, countries long-term growth. Among these instruments, a pivotal role is played by public procurement, largely recognized as a powerful driver of technological upgrading and industrial renewal (Edquist, 2015).

This work fills a gap in the empirical literature by analysing the impact of PP on industries' patenting activities for 24 countries over the period 1995-2011. Enriching a largely qualitative literature, this analysis provides a quantitative account of the role of PP as innovation driver. In addition, the relationship between PP and innovation is studied taking into consideration the potentially moderating effect of import penetration of PP. Finally, in order to capture the role of both institutional and technological heterogeneity, the analysis is replicated on three industry-level subsamples. By limiting the estimation to European industries, we firstly test whether institutional differences - i.e. in particular, differences concerning the degree of openness of domestic PP to foreign producers - dividing Europe and the other countries included in the sample - i.e. Japan, Korea, Russia, Turkey and the US - affects magnitude and shape of the investigated relations. Second, we separately analyse high and low-tech sectors so to verify if the effect of PP on patents changes depending on industries technological characteristics.

The main results can be summarized as follows. First of all, PP emerges as a strong innovation driver. All across the estimations, a positive and strongly significant association between PP and industries' patenting activities is detected. This is true for both the 'regular' PP indicator as well as for the PP innovation propensity index - i.e. the index that weights industries' PP by the countrylevel share of public expenditure devoted to R\&D activities. Remarkably, such association is significant despite controlling for technology-push and demand-pull factors such as R\&D expenditure and exports. In this respect, PP is identified as an element exerting an additional and positive effect on industries innovativeness summing up over the other traditional technology-push and demand-pull drivers.

The second finding regards the role of import penetration. Confirming the expectations, industries displaying a relatively stronger import penetration are characterized by a significant reduction in the 
pro-innovative effect of PP, as testified, in all the estimations, by the negative sign of the coefficient of the PP-import penetration interaction term.

The test on European industries provides some additional insights. The positive impact of PP on patents emerging from the baseline estimation is confirmed. Such positive effect is detected irrespectively from the variable used to measure PP. The key difference, however, regards import penetration. In the European case, the moderating effect of import penetration operates for both the regular and for the 'innovation augmented' PP differently to the baseline case where only the regular PP-import penetration interaction resulted negative and significant. In Europe, thus, an excessive openness to foreign competition seems to negatively affect the innovation spurring effect of PP in spite of the heterogeneous innovation propensity characterizing EU member states' governments. From this point of view, these findings seems to support the recent President Macron's proposal regarding the adoption of a 'Buy Europe' Act analogous to the one launched in the US after the 2008 crisis. ${ }^{13}$ Such proposal, in fact, recognizes that in order to maximize PPrelated economic and technological benefits EU economies should properly calibrate procurement's degree of openness.

Finally, the relationship between PP and industries patents stock is not significantly altered when high and low tech industries are separately taken into account. In the high-tech case, the results strongly overlap what emerged estimating the full sample model. When it comes to low-tech industries, PP is again identified as a powerful innovation driver. This result reveals the PP's capacity to stimulate a process of technological upgrading in sectors traditionally less prone to the introduction of innovations. The moderating effect of import penetration, in turn, seems to operate in both the high and the low-tech cluster.

In terms of policy implications, this work provides a strong claim in favour of PP as a crucial instrument to spur innovativeness and to favour industrial renewal and technological upgrading. In this sense, this study strengthen the arguments put forth by the qualitative literature emphasizing the pro-innovative stance of PP. Moreover, the findings on the moderating effect of import penetration suggest that decisions concerning the degree of openness of PP should be carefully undertaken avoiding any penalization of the PP pro-innovative effects.

\section{Acknowledgements}

This paper is produced as part of ISIGrowth project on Innovation fuelled, Sustainable, Inclusive Growth that has received funding from the European Union's Horizon 2020 research and innovation programme under grant agreement No. 649186 - ISIGrowth. The authors wish to thank Elvira Uyarra

\footnotetext{
${ }^{13}$ For a synthetic description of the Macron's Buy Europe proposal see the Financial Times article by Chassany (2017).
} 
and the participants at the Eurkind GCW 2016 Conference for their comments as well as the participants at the EU-SPRI 2017 Conference in Vienna.

\section{References}

Andreoni, A. and Chang, H.J. (2016) Industrial policy and the future of manufacturing, Economia e Politica Industriale: Journal of Industrial and Business Economics, 43, issue 4, p. 491-502.

Andreoni, A. and Scazzieri, R. (2014). Triggers of change: Structural trajectories and production dynamics. Cambridge Journal of Economics, 38(6), 1391-1408.

Antonelli C. (1999) The Microdynamics of Technological Change, London, Routledge.

Appelt, S. and Galindo-Rueda, F. (2016) Measuring the link between public procurement and innovation, OECD Science, Technology and Industry Working Papers, 2016/03, OECD Publishing, Paris. http://dx.doi.org/10.1787/5jlvc7s11w7h-en

Arrow, K. (1962). The Economic Implications of Learning by Doing. The Review of Economic Studies, 29(3), 155-173.

Beviglia-Zampetti, A. (1997) The UNCITRAL model law on procurement of goods, construction and services. Hoekman and Mavroidis.

Bogliacino, F. and Pianta, M. (2012). Profits, R\&D, and innovation-a model and a test. Industrial and Corporate Change, 22(3), 649-678.

Bogliacino, F. and Pianta, M. (2016). The Pavitt Taxonomy, revisited: patterns of innovation in manufacturing and services. Economia Politica, 33(2), 153-180.

Bresnahan, T. and Greenstein, S (2001) The economic contribution of information technology: Towards comparative and user studies, Journal of Evolutionary Economics, 11(1), pp. 95-118.

Brulhart, M. and Trionfetti, F. (2004) Public expenditure, international specialisation and agglomeration", European Economic Review, 48(4), pp. 851-81.

Cabral, L., Cozzi, G., Denicolo, V., Spagnolo, G. and Zanza, M. (2006) Procuring innovations, in: N. Dimitri, G. Piga \& G. Spagnolo (Eds) Handbook of Procurement, pp. 483-530 (Cambridge, MA: Cambridge University Press).

Cameron A. C., Trivedi P. K. (1998). Regression Analysis of Count Data. Econometric Society Monograph No.30, Cambridge University Press.

Cave J and Frinking E (2003) Public procurement and R\&D: Short analysis of the potential and practices. In: Gavigan JP (ed.) Public Procurement and R\&D: A JRC/IPTS-ESTO Fast Track Working Paper. Paris: European Commission Joint Research Centre-Institute for Prospective Technological Studies, European Science and Technology Observatory, pp.11-44.

Chang, H-J. (1994) The Political Economy of Industrial Policy. London and Basingstoke: Macmillan. 
Chang H.J. and Andreoni A. (2016) Industrial Policy in a Changing World: Basic Principles, Neglected Issues and New Challenges, paper for the Cambridge Journal of Economics 40Years Conference.

Cahssany, A. S. (2017) Macron wants tougher EU on trade and foreign investment. Financial Times, May 11, 2017. Available at: https://www.ft.com/content/38e98f94-359b-11e7-99bd13 beb0903fa3 [accessed the $15^{\text {th }}$ of June 2017]

Cirillo, V. and Guarascio, D. (2015) Jobs and Competitiveness in a Polarised Europe, Intereconomics, 50(3), pp. 156-160.

Cohen, E. (2007) Industrial policies in France: the old and the new. Journal of Industry, Competition and Trade 7:213-227.

Crespi, F. and Pianta, M. (2007) Innovation and demand in European industries. Economia Politica-Journal of Analytical and Institutional Economics 24(1):79-112

Crespi F. and Quatraro F. (2013) Systemic technology policies: Issues and instruments. Technological Forecasting \& Social Change, Vol. 80, pp.1447-1449.

Edler, J. and Georghiou, L. (2007) Public Procurement and Innovation - Resurrecting the Demand Side. Research Policy, 36(7), pp. 949-963.

Edquist, C. and Hommen, L. (2000) Public Technology Procurement and Innovation Theory; in Edquist, C., Hommen, L. e Tsipouri, L. (Eds.) (2000) Public Technology Procurement and Innovation. Kluwer Academic.

Edquist, C., Vonortas, N. S., Zabala-Iturriagagoitia, J. M. and Edler, J. (Eds.). (2015, January). Public Procurement for Innovation. Cheltenham: Edward Elgar Publishing.

Edquist, C. (2015) Innovation-related Public Procurement as a Demand-oriented Innovation Policy Instrument, Circle papers in innovation studies, Lund University, n. 2015/28

European Commission (2011) Commission staff working paper: Impact and Effectiveness of EU Public Procurement Legislation, Bruxelles.

Geroski, P. (1990) Procurement policy as a tool of industrial policy, International Review of Applied Economics, N. 4, 182-198.

Geroski, P. A. and Walters, C. F. (1995). Innovative activity over the business cycle. The Economic Journal, 916-928.

Georghiou, L., Edler, J., Uyarra, E. and Yeow, J. (2014) Policy instruments for public procurement of innovation: Choice, design and assessment Technological Forecasting and Social Change, n.86, pp: $1-12$

Griliches, Z. (1990) Patent statistics as economic indicators: a survey. Journal of Economic Literature, Vol. 28, pp. 1661-1707. 
Guarascio, D., Pianta, M., Lucchese, M. and Bogliacino, F. (2015). Business cycles, technology and exports. Economia Politica, 32(2), 167-200.

Guarascio, D., Pianta, M. and Bogliacino, F. (2016). Export, R\&D and new products. a model and a test on European industries. Journal of Evolutionary Economics, 26(4), 869-905.

Guarascio, D. and Pianta, M. (2016). The gains from technology: new products, exports and profits. Economics of Innovation and New Technology, 1-26.

Jaffe, A.B. and Trajtenberg, M. (2004) Patents, Citations, and Innovations: A Window on the Knowledge Economy. Journal of Economic Literature, Vol. 42, pp. 1158-1160.

Kaldor, N. (1981) The role of increasing returns, technical progress and cumulative causation in the theory of international trade and economic growth, Economie Appliquee, no. 4

Kleinknecht A. and Verspagen B. (1990) Demand and innovation: Schmookler re-examined, Research Policy, vol. 19, pp. 387-394.

Kleinknecht, A. (Ed.). (1996) Determinants of innovation. Springer.

Leon P. (1967) Structural Change and Growth in Capitalism: A Set of Hypotheses, Baltimore, John Hopkins.

Lowinger, T. C. (1976). Discrimination in government procurement of foreign goods in the US and Western Europe. Southern Economic Journal, 451-460.

Lucchese, M., Nascia, L. \& Pianta, M. (2016). Industrial policy and technology in Italy, Economia e Politica Industriale: Journal of Industrial and Business Economics, 43, issue 3, p. 233-260.

Lybbert T. J. and Zolas N. J. (2014) Getting patents and economic data to speak to each other: An Algorithmic Links with Probabilities' approach for joint analyses of patenting and economic activity, Research Policy, Vol. 43 pp. 530-542.

Malerba, F. (2007) Innovation and the dynamics and evolution of industries: Progress and challenges, International Journal of Industrial Organization, 25(4), pp. 675-699.

Mazzucato, M. (2013) The Entrepreneurial State: Debunking the Public vs. Private Myth in Risk and Innovation. London: Anthem.

Mazzucato, M., Cimoli, M., Dosi, G., Stiglitz, J., Landesmann, M., Pianta, M., Walz, R. and Page, T. (2015) Which Industrial Policy Does Europe Need? Intereconomics: Review of European Economic Policy, vol. 50(3), pp. 120-155.

Mazzucato, M. (2016). From market fixing to market-creating: a new framework for innovation policy. Industry and Innovation, 23(2), 140-156.

Messerlin, P. e Mirodout, S. (2012) EU Public Procurement Markets: How Open are they?

SciencesPo, Groupe de Economie Mondiale, Policy Brief, August, 2012. 
Miyagiwa, K. (1991) Oligopoly and discriminatory government procurement policy. The American Economic Review, 81(5):1320_1328.

Mowery D. and Rosenberg N. (1979) The influence of market demand upon innovation: a critical review of some recent empirical studies, Research Policy, vol. 8, pp. 102-153.

OECD (2011) Demand-side Innovation Policies. Luxembourg: OECD Publishing.

Pasinetti L. (1981) Structural Change and Economic Growth, Cambridge: Cambridge University Press.

Peneder, M. (2017). Competitiveness and industrial policy: from rationalities of failure towards the ability to evolve, Cambridge Journal of Economics, vol. 41, no. 3, 829-858-

Pianta, M. (2015) What Is to Be Produced? The Case for Industrial Policy, Intereconomics, Forum Industrial Policy: Which Industrial Policy Does Europe Need? 50(3), pp. 120-155

Porter, M. E. (1990) The Competitive Advantage of Nations (New York: Free Press).

Rickard, S. J. and Kono, D. Y. (2014) Think globally, buy locally: International agreements and government procurement. The Review of International Organizations, 9(3), 333-352.

Rothwell, R. and Zegveld, W. (1981). Industrial Innovation and Public Policy: Preparing for the 1980s and the 1990s (No. 42). Greenwood Pub Group.

Scherer F.M. (1982) Demand-Pull and Technological Invention: Schmookler Revisted, The Journal of Industrial Economics, vol.30, pp.225-237.

Schmookler J. (1966) Invention and Economic Growth, Cambridge (MA), Harvard University Press.

Simonazzi, A., Ginzburg, A. and Nocella, G. (2013) Economic Relations between Germany and Southern Europe, Cambridge Journal of Economics, 37 (3), pp. 653-675.

Stiglitz, J. E. and Greenwald, B. C. (2014) Creating a learning society: A new approach to growth, development, and social progress. Columbia University Press.

Ramboll Management Consulting and HTW Chur, (2012) Cross-border Procurement above EU Threshold. Ramboll, Copenhagen.

Rothwell, R. (1983) Creating a regional innovation-oriented infrastructure: The role of public procurement. Paper submitted to the Conference on Public Procurement and Regional Policy. University of Neuchâtel (31.19-1.11.1983)

Timmer, M.P., Dietzenbacher, E., Los, B., Stehrer, R. e de Vries, G.J. (2015) An Illustrated User Guide to the World Input-Output Database: the Case of Global Automotive Production, Review of International Economics.

Trionfetti, F. (2000) Discriminatory public procurement and international trade, World Economy, 23(1), pp. 57-76. 
Von Hippel, E. (1986) Lead users: A source of novel product concepts, Management Science, 32(7), pp. 791-805.

Yanchao, L. (2014) Public procurement to drive innovation in China. United Nations Office for Project Services (UNOPS).

Wade, R. (1990) Governing the Market: Economic Theory and the Role of Government in East Asia's Industrialization. Princeton: Princeton University Press.

Wade, R. (2017) The American paradox: ideology of free markets and the hidden practice of directional thrust, Cambridge Journal of Economics vol. 41, no. 3, 859-880

Weiss, L. and Thurbon, E. (2006). The Business of Buying American: Public Procurement as Trade

Strategy in the USA. Review of International Political Economy, 13(5), pp.701-724.

Uyarra, E. and Flanagan, K. (2010). Understanding the Innovation Impacts of Public Procurement. European Planning Studies, 18 (1): 123-143.

\section{Appendix}

\section{Matching patent data and industrial classifications}

The concordance system proposed by Lybbert and Zolas (2014) rely on data mining methods and probabilistic matching allowing to create direct linkages between patent data and a variety of economic classification schemes. Using the Algorithmic Links with Probabilities (ALP) approach, country-level information on patents are examined identifying relevant keywords extracted from industry classification descriptions. The search is performed using patent titles and abstracts. Then, patents are tabulated by IPC code, and frequency matches between the industry-level classification - i.e. NACE - and IPC classifications are performed. By analysing these frequencies, IPC and industrial classification are finally matched.

The patents assigned for each year to the specific sector/country combination are used to compute the patent stock as a measure of the installed technological capability at the sector level. The 'depreciation' of the stock is than taken into account by applying a standard decay rate. Formally, the procedure adopted to build the patent stock can be expressed as follows (4):

$$
K P A T_{i, t}=\sum_{s=1}^{t} P A T_{i, s} e^{[-\mu(t-s)]}(4)
$$

where $P A T_{i, s}$ represents the number of patents applied in country $\mathrm{i}$ in year s where s represents an index of years up to and including year $t$, whereas $\mu$ is the decay rate, here assumed as a standard $15 \%$ value. 


\section{The revised Pavitt taxonomy}

The separate test on high and low-tech sectors is performed relying on the revised Pavitt taxonomy proposed by Bogliacino and Pianta (2016). The following table reports the list of sectors divided by Pavitt class and according to the HT (Science Based and Specialized Suppliers) - LT (Supplier Dominated and Scale Intensive) grouping used for the econometric analysis.

Table A1. The classification of sectors adopted for the HT - LT test

\begin{tabular}{|c|c|c|c|c|}
\hline & SECTORS (NACE Rev.1) & $\begin{array}{c}\text { Nace } \\
\text { Codes }\end{array}$ & Pavitt class & $\begin{array}{c}\text { High (HT) } \\
\text { and Low } \\
(\text { LT) } \\
\text { technology } \\
\text { sectors* } \\
\end{array}$ \\
\hline Nr. & MANUFACTURING & & & \\
\hline 1 & FOOD PRODUCTS, BEVERAGES AND TOBACCO & $15-16$ & SD & LT \\
\hline 2 & TEXTILES & 17 & SD & LT \\
\hline 3 & WEARING APPAREL, DRESSING AND DYEING & 18 & SD & LT \\
\hline 4 & LEATHER, LEATHER PRODUCTS AND FOOTWEAR & 19 & SD & LT \\
\hline 5 & WOOD AND PRODUCTS OF WOOD AND CORK & 20 & SD & LT \\
\hline 6 & PULP, PAPER AND PAPER PRODUCTS & 21 & SI & LT \\
\hline 7 & PRINTING AND PUBLISHING & 22 & SI & LT \\
\hline 8 & CHEMICAL AND CHEMICAL PRODUCTS & 24 & SB & HT \\
\hline 9 & RUBBER AND PLASTIC PRODUCTS & 25 & SI & LT \\
\hline 10 & OTHER NON-METALLIC MINERAL PRODUCTS & 26 & SI & LT \\
\hline 11 & BASIC METALS & 27 & SI & LT \\
\hline 12 & FABRICATED METAL PRODUCTS (EXCEPT MACHINERY AND EQUIPMENT) & 28 & SD & LT \\
\hline 13 & MACHINERY AND EQUIPMENT, NEC & 29 & SB & HT \\
\hline 14 & OFFICE, ACCOUNTING AND COMPUTING MACHINERY & 30 & SB & HT \\
\hline 15 & ELECTRICAL MACHINERY AND APPARATUS, NEC & 31 & SS & HT \\
\hline 16 & RADIO, TELEVISION AND COMMUNICATION EQUIPMENT & 32 & SB & HT \\
\hline 17 & MEDICAL PRECISION AND OPTICAL INSTRUMENTS & 33 & SB & HT \\
\hline 18 & MOTOR VEHICLES, TRAILERS AND SEMITRAILERS & 34 & SI & LT \\
\hline 19 & OTHER TRANSPORT EQUIPMENT & 35 & SS & HT \\
\hline 20 & MANUFACTURING NEC AND RECYCLING & 36 & SD & LT \\
\hline
\end{tabular}

* The high and low-tech classification is made relying on the revised Pavitt taxonomy for manufacturing and services (Bogliacino and Pianta, 2016). Industries belonging to the Science Based (SB) and Supplier Specialized (SS) are included in the high-tech group while Supplier Dominated (SD) and Scale Intensive (SI) in the low-tech one. We include in the low-tech group also the following Supplier Dominated service sectors: inland transport (61), water transport (62), air transport (63) and transport auxiliary activities (64); as well as the agricultural and haunting (AtB), mining (C), electricity and gas (E) and the construction (F) sectors. 